\title{
VAGUENESS AND THE PROBLEM OF EVIL: A NEW REPLY TO VAN INWAGEN
}

\author{
LUIS OLIVEIRA \\ https:/ / orcid.org/0000-0001-7478-1469 \\ University of Houston \\ Department of Philosophy \\ Houston, Texas \\ U.S.A. \\ lrolivei@central.uh.edu
}

\begin{abstract}
Article info
CDD: 200.1

\section{Keywords}

Vagueness

Problem of Evil

Peter van Inwagen
\end{abstract}

Received: 26.07.2021; Accepted: 15.08.2021

https://doi.org/10.1590/0100-6045.2021.V44N4.LO

\begin{abstract}
One of the few points of agreement between most theists and non-theists working on the problem of evil is that the existence of a perfect God is incompatible with the existence of pointless evil. In a series of influential papers, however, Peter van Inwagen has argued that careful attention to the reasoning behind this claim reveals fatal difficulties related to the Sorites Paradox. In this paper, I explain van Inwagen's appeal to sorites reasoning, distinguish between two different arguments in his work, and argue that they both commit the same so-far-unnoticed mistake.
\end{abstract}

\section{Introduction}

Most of us are bothered by much of the suffering that we see. Most of us wouldn't think twice before intervening if we could. We would prevent assault and murder, protect life and limb under the rubble of an earthquake, soothe the hardships 
of poorly paid day-laborers, abolish the very possibility of painful death by slow disease for innocent young children, and so on. We see no point to that kind of pain, and no point to much else besides. There doesn't seem to be anything, as far as we can tell, that would justify us in permitting all of that to continue to go on - especially at the rate and scope that it does daily - if we had the power to make it stop. Our ordinary experience of the world, that is, is filled with instances of what we can call apparently pointless evil.

This is not to say that all or any of this evil is, in fact, pointless. Maybe it just seems so from our limited perspective. Nonetheless, some of us have insisted that the mere fact that so much of it seems pointless is enough to make it reasonable to reject a particularly common religious belief: that this world was created by a perfectly good and perfectly powerful being that personally cares for each and every one of us - and does so in ways that are not unintelligibly different from the ways in which we care for the ones we love. In what is now a classic statement, William Rowe (1979) captured this line of reasoning with the following argument:

\section{Rowe's Evidential Argument from Evil}

R1. After careful reflection on our experience and knowledge, we see no justifying reason for many instances of suffering in the world.

R2. If, after careful reflection on our experience and knowledge, we see no justifying reason for many instances of suffering in the world, then it is reasonable to believe that there is no justifying reason for at least some of all that suffering. 
C1. So it is reasonable to believe that there is no justifying reason for at least some of the suffering in the world.

R4. If there is even one instance of suffering for which there is no justifying reason, then God does not exist.

C2. So it is reasonable to believe that God does not exist.

This argument does not pretend to show that God does not exist - where by 'God', recall, we only mean the kind of perfect, personal being mentioned above. It doesn't even pretend to show that religious believers are unreasonable in their beliefs. All that this argument tries to do is show is that the existence of too much apparently pointless evil can make it reasonable to reject belief in God, provided one falls under the scope of the "we" in R1 and R2. So the basis of Rowe's argument is a widely shared experience (of apparently pointless evil) and the conclusion is fairly modest and circumscribed. I think the argument is basically right. ${ }^{1}$

Of course, many reasonable philosophers reasonably disagree. Not satisfied with being reasonable in their religious beliefs, many think the reasoning above is insufficient to support someone else's disbelief instead. There is a long and venerable tradition, for example,

${ }^{1}$ In Oliveira (2020), I have defended the argument stated just above as an accurate exegesis of the argument constituted by Rowe's complete reasoning in his 1979 text. Differently from a more popular reading, mine sees in the core of Rowe's argument an appeal to the large collection of apparently pointless evils, as opposed to an appeal to a single instance instead. 
suggesting that truly careful reflection on our experience and knowledge - as opposed to merely cursory and superficial reflection - reveals a variety of justifying reasons, or possible justifying reasons, for all the evils that we see. These accounts are sometimes called theodicies or defenses and, especially together, they pose a serious challenge to R1. There are also ever more sophisticated versions of a simple line of thought: we are too limited in our cognitive powers; we wouldn't be able to see the point behind most of the evil in this world even if they did in fact have a point; isn't it height of hubris to think that something we wouldn't see anyway is just not there? This kind of reply is sometimes called skeptical theism and it poses a serious challenge to R2. Perhaps these challenges to R1 and R2 are right, perhaps they are wrong. Either way, I won't have much to say about them here today. ${ }^{2}$

Today I am interested in a particular challenge to R4 instead. First, here is why I think R4 is true. If God cares for me in particular (as opposed to caring only for certain collective properties of His creation, such as average individual well-being, the historical development of humanity as a whole, and so on) and has the power and knowledge to prevent my suffering on any particular occasion, then it seems to me that He would not allow some evil to befall me unless he had correctly identified, in his omniscience, justifying reasons for doing so. To me, this seems like a very minimal requirement on saying that God is

${ }^{2}$ For important discussions of theodicies and defenses, see Hick (1966), Plantinga (1974), van Inwagen (1988), and Adams (1999). For the important discussions of skeptical theism, see Wykstra (1984), Alston (1996), Bergmann (2001), and Perrine and Wykstra (2012). In my (2020), I have defended Rowe's argument against the skeptical theist. I defend Rowe's argument against theodicies and defenses in a manuscript currently under review. 
a perfectly powerful and perfectly good being that cares for me (again: in ways that are not unintelligibly different from the ways in which we typically use those words). ${ }^{3}$ Think about it. A parent who allows their child to suffer through a painful episode which they (a) knew was coming, (b) knew how to prevent, and (c) had no justifying reason to allow, is not caring for their child in that moment. All the more so for a God of unlimited resources. I suspect that many who at first resist R4 are mistakenly ignoring the fact that R4 is explicitly about possible cases where God would have no justifying reasons whatsoever for some particular evil - as opposed to cases where we just don't see His reasons for it. But it is only those committed to claiming that there are instances of evil for which a perfect God could have no justification - for which God would say, without displaying any imperfection, "I'm sorry but there is nothing that justifies my permission of this particular evil; I knew of it, I could have prevented it, I saw no reason not to prevent it, but I still did nothing about it" - that are truly denying R4. I find that simply incredible.

Nonetheless, what one philosopher finds incredible, another philosopher defends with careful and incisive argument. That's philosophy for you. My goal today, then, is examining and responding to Peter van Inwagen's (1988, 1991, 2001, 2006) well known misgivings about R4. According to van Inwagen, the reasoning behind R4 runs into age-old difficulties related to the Sorites Paradox. After explaining how this paradox is relevant to our discussion

\footnotetext{
3 "But that's the point," you may say, "God is powerful and good precisely in ways that are unintelligibly different from our own understanding of power and goodness!" Alright. I then reply: "Perhaps. But now, by your own admission, the content of your claim that God is perfectly powerful and perfectly good is unintelligible to you and me. That's hardly a good reason for me to believe it."
} 
(Section 1), I extract two arguments against R4 from van Inwagen's work (Section 2) and argue that they both fall short on account of the same underlying mistake (Section 3). If I am right, what is revealed is that van Inwagen's challenge, though influential, is no challenge after all.

\section{The Sorites Paradox and Practical Soritification}

Instances of the Sorites Paradox arise whenever our language makes use of vague predicates. For our purposes, it will suffice to say that vague predicates are those that satisfy the following condition (cf. Wright 1975):

Tolerance: For any $a$ that is or is not F, small F-related changes in $a$ do not affect whether $a$ is or is not F.

If a predicate $\mathrm{F}$ satisfies Tolerance, then it is hard to tell exactly where to draw a line between cases where $\mathrm{F}$ is applicable and cases where F is not. This doesn't mean that there aren't clear cases where F applies and clear cases where it doesn't. What it means is that there will be borderline cases, cases where it is hard to tell whether $\mathrm{F}$ applies or not. Consider the predicate "being bald". Take anyone with any amount of hair: whatever you say regarding them being bald or not, that assessment will not change with the addition or subtraction of just one single hair. That's because the predicate "being bald" satisfies Tolerance. Consequently, it is hard to tell exactly where to draw a line between those people whom we would call bald and those whom we would not, and, consequently, there are groups of people of whom it is hard to tell if they are or are not bald - there are, that is, borderline cases of baldness. All of this should be uncontroversial. 
To see how vague predicates such as "being bald" lead us into paradox, consider what seems to be a flawless piece of reasoning. Pick any vague predicate F, such as "being bald". Take the notation " $F a_{n-1}, \mathrm{Fa}_{n}, \mathrm{Fa}_{\mathrm{n}+1}$ " to indicate borderline cases subject to toleration: if $\mathrm{F}$ applies to " $\mathrm{a}_{\mathrm{n}}$ ", then it applies to " $a_{n-1}$ " and " $a_{n+1}$ " as well; and vice versa. Now take $a_{0}$ to be a clear case where F does apply (someone without a single hair, for example) and $\mathrm{a}_{1000}$ to be a clear case where $\mathrm{F}$ does not apply (someone with a full head of hair, for example). All we need now is our trusty modus ponens:

$$
\begin{aligned}
& \text { True }\left\{\begin{array}{l}
\text { 1. } \mathrm{Fa}_{0} \\
\text { 2. } \sim \mathrm{Fa}_{1000}
\end{array}\right. \\
& \text { Sorites } \begin{array}{l}
\text { 3. } \mathrm{Fa}_{0} \rightarrow \mathrm{Fa}_{1} \\
\text { 4. } \mathrm{Fa}_{1} \rightarrow \mathrm{Fa}_{2} \\
\ldots \\
\mathbf{X} . \mathrm{Fa}_{999} \rightarrow \mathrm{Fa}_{1000}
\end{array} \\
& \text { Reasoning } \\
& \text { False }\left\{\begin{array}{l}
\text { C1. } \mathrm{Fa}_{1000} \\
\text { C2. } \mathrm{Fa}_{1000} \text { and } \sim \mathrm{Fa}_{1000}
\end{array}\right.
\end{aligned}
$$

This is what we can call a sorites argument: reasoning through small and innocuous changes straight into a contradiction. In most cases, though maybe not all, we think that something has gone wrong if we reach a contradiction. The suggestion that someone with a full and flowing head of hair both is and is not bald, at least, certainly seems false. But where did our reasoning go wrong? Nowhere, it seems. We seem to have flawless reasoning leading us from clear truth to unmistakable falsehood. That's the paradox. 
Much has been written about vagueness and the Sorites Paradox. ${ }^{4}$ But our interest here is not in those details. Rather, our interest is in van Inwagen's claims about the impact of that paradox on practical reasoning. Much of our practical reasoning, though again not all, proceeds via the application of general principles to particular cases: from our acceptance of some general rule, combined with the features of our circumstances, we derive a more particular prescription. Suppose I tell myself that I shouldn't eat sugar for a week; after examining the label of a certain protein bar, I then decide it is okay to eat it. When I proceed in this way, it is because I have concluded (tacitly, in most cases) that this behavior is permitted by some principle I endorse. In other words, I have concluded that this behavior is not a violation of that principle, that the principle does not prescribe that I don't do this, and so on. This kind of principle-based practical reasoning is even more explicit in contexts where we are expected to publicly justify our choices. When asked why we decided to do A - raise taxes, lower grades, fire someone, dismiss a motion, and so on - we often reply that doing A was prescribed by some principle $\mathrm{P}$ or that some relevant $\mathrm{P}$ did not prescribe against it. This much should be uncontroversial too.

Some of the principles we use in private and public deliberation, however, make central use of vague predicates. Suppose George is a dedicated and conscientious groundskeeper. As he waters some lawn in the heat of Summer, he is committed to using just the exact amount of water that is necessary for the health of the grass. George is guided, in other words, by the following principle:

${ }^{4}$ See, for example, Wright 1975, Kamp 1981, Williamson 1994 , Sorensen 2001, Raffman 2014, as well as the essays collected in Oms and Zardini (2019). 
W: If $\mathrm{n}$ amounts of water are necessary for the health of the lawn, then I ought to provide the lawn with at least $\mathrm{n}$ amounts of water. If $\mathrm{n}$ amounts of water are not necessary for the health of the lawn, then I ought to not provide the lawn with $\mathrm{n}$ or $\mathrm{n}+$ amounts of water.

But now suppose, plausibly, that some amount of water is obviously necessary for the health of the lawn: e.g., 5 gallons. By W, it then follows that George ought to provide the lawn with at least 5 gallons of water. Similarly, suppose that some amount of water is obviously not necessary for the health of the lawn: e.g., 100 gallons. By W, it then follows that George ought to not provide the lawn with 100 gallons of water. The problem, however, is that "is necessary for the health of the lawn" is a vague predicate. And this means, recall, that small changes in the target of the predicate do not alter the appropriateness of its application. Take any amount of water, that is, and whatever you say regarding it being necessary or not for the health of the lawn, that assessment will not change with the addition or subtraction of just one fluid ounce. This is a recipe for disaster.

Consider this bit of Sorites reasoning from our dedicated and conscientious groundskeeper: 
True $\left\{\begin{array}{l}1.5 \text { gallons of water are necessary for the health of the lawn. } \\ 2.100 \text { gallons of water are not necessary for the health of the lawn. }\end{array}\right.$

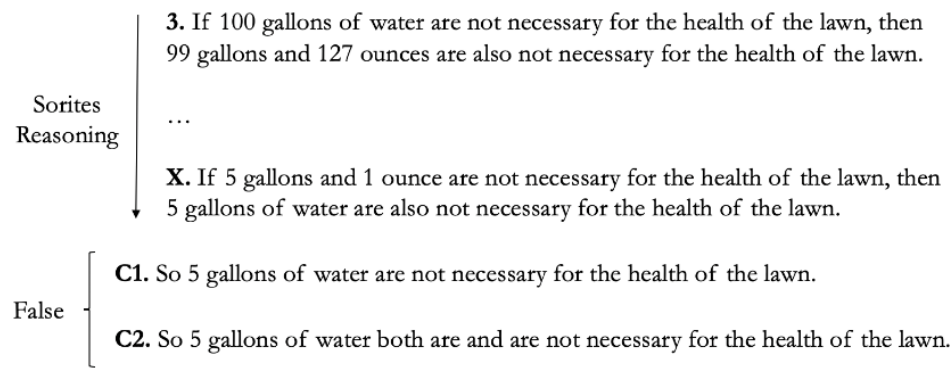

As we have already seen, this is flawless reasoning. Paradoxical, yes, but flawless nonetheless. But if $\mathrm{W}$ is true, then it follows from C2 that George both ought to provide the lawn with 5 gallons of water and ought to not provide the lawn with 5 gallons of water. Disturbingly, we have now derived contradictory prescriptions from the very same principle, owing to the centrality of its use of a vague predicate. Principle W, as I will say, is thus subject to practical soritification:

Practical Soritification: The valid derivation of a false prescription from principle $\mathrm{P}$ by way of sorites reasoning alone.

This is certainly a bad thing. As van Inwagen (2001, 73; $2006,102)$ rightly puts it, practical soritification is a reductio ad absurdum of principles like W. This can be so simply because $\mathrm{W}$ leads to an absurd prescription we antecedently and justifiably believe to be false (i.e., C1), or perhaps because $\mathrm{W}$ leads to an absurd prescription that is false by 
virtue of being contradictory (i.e., C2). Either way, practical soritification reveals a serious problem for any principle that is subject to it. ${ }^{5}$ As we will see next, this is the main arrow in van Inwagen's quiver against R4.

\section{2. van Inwagen's Two Arguments Against R4}

Our interest today, recall, is with van Inwagen's arguments against Rowe's R4.

R4. If there is even one instance of suffering for which there is no justifying reason, then God does not exist.

There are two such arguments. One argument is what I will call the direct argument, since its premises do not depend on anything else one believes about the problem of evil and its potential resolution. I will call the other argument the indirect argument, since its premises depend on a particular story that van Inwagen offers as a plausible account of God's reasons for much of the evil that we see. These two arguments, however, have not been clearly distinguished in the literature around van Inwagen's work, so I will extract and state them clearly in this section. In the next section, I will argue that they both fall prey to the same hitherto unidentified defect.

\footnotetext{
5 On this matter, Meghan Sullivan $(2013,401)$ suggests that "practical sorites problems arise whenever an agent tries to apply a policy in a situation that meets the following criteria: (1) the policy's condition is susceptible of indeterminacy (including higher-order indeterminacy), (2) the policy is being applied in a context where its indeterminate cases exist, and (3) the policy only has determinate mandates."
} 


\section{1. van Inwagen's Direct Argument}

Here is the version of R4 that van Inwagen (2001, 69; $2006,98)$ puts in the mouth of his Atheist character when she is offering an argument explicitly modeled on Rowe's:

R4*: If a morally perfect creator could have left a certain horror out of the world he created, and if the world he created would have been no worse if that horror had been left out of it than it would have been if it had included that horror, then the morally perfect creator would have left the horror out of the world he created - or at any rate he would have left it out if he had been able to.

The differences between R4* and R4 are merely due to a difference in their level of abstraction. R4 tells us that a perfect God cannot co-exist with "unjustified evil," while R4* unpacks the notion of an unjustified evil with a particular normative framework. The idea here, in other words, is that what it means for something to be an unjustified evil is for it to be such that a morally perfect creator could have left it out of the world without making it worse than it would have been with it. If this is not what R4* means to say, then its consequent does not follow. Taken in this way, moreover, a challenge to R4* is ipso facto a challenge to R4.

But why should we think that R4 or R4* are true? As van Inwagen $(2001,71 ; 2006,100)$ puts it (through his characters Theodore and Theist), "I believe there is really just one moral principle that it would be plausible to appeal in defense of premise 3 [i.e., R4*]...”: 
Moral Principle (MP): If one is in a position to prevent some evil, one should not allow that evil to occur - not unless allowing it to occur would result in some good that would outweigh it or preventing it would result in some other evil at least as bad.

Once again, we can get a normatively-generic version of MP if we substitute "allowing it to occur would result in some good that would outweigh it or preventing it would result in some other evil at least as bad" with "one had a justifying reason for allowing it."6 Unfortunately, according to van Inwagen, MP is subject to practical soritification. van Inwagen $(2001,72-3 ; 2006,100-1)$ shows this by considering an example I will call Sentence:

Sentence: Suppose you are an official who has the power to release anyone from prison at any time. Blodgett has been sentenced to ten years in prison for felonious assault. His sentence is nearing its end, and he petitions you to release him from prison a day early. Should you? Well, the principle says so. A day spent in prison

\footnotetext{
${ }^{6}$ Anyone who is not a strict consequentialist will already think that R4* and MP are both false, and will dismiss as silly the suggestion that that MP is the only plausible moral principle behind R4. Aside from goods we should promote and the reasons we so acquire, it is plausible that there are goods we should respect and reasons related to that as well. Since my concerns in this paper apply just as well to the normatively generic versions of these claims, I will proceed by mostly using van Inwagen's more restrictive language..
} 
is an evil... Let's suppose that the only good that results from someone's being in prison is the deterrence of crime... Obviously, 9 years and 364 days spent in prison is not going to have a significantly different power to deter felonious assault from 10 years spent in prison. So: no good will be secured by visiting on Blodgett that last day in prison, and that last day spent in prison is an evil. The principle tells you, the official, to let him out a day early.

The problem now is that the same reasoning can be repeated over and over, since the predicate "is necessary for deterrence" is vague. As van Inwagen $(2006,101)$ puts it, "a moment's reflection shows that if this is true, as it seems to be, then the moral principle entails that Blodgett ought to spend no time in prison at all" (my emphasis). The kind of reflection van Inwagen has in mind is precisely the kind we considered in the previous section.

Suppose that some amount of the evil of prison time is obviously necessary for the outweighing good of deterrence: e.g., 1 day. By MP, it then follows that the official in Sentence ought to sentence Blodgett to at least 1 day in prison. Similarly, suppose that some amount of time is obviously not necessary for deterrence: e.g., 100,000 days. By MP, it then follows that the official in Sentence ought to not sentence Blodgett to 100,000 days in prison. But since "is necessary for deterrence" is a vague predicate, small changes in the target of that predicate do not alter the appropriateness of its application. Take any amount of time, that is, and whatever you say regarding it being necessary or not for deterrence, that assessment will not change with the addition or subtraction of just one hour. 
Now consider this bit of Sorites reasoning from the official in Sentence:

True $\left\{\begin{array}{l}1.1 \text { day in prison for Blodgett is necessary for deterrence. } \\ \text { 2. 100,000 days in prison for Blodgett are not necessary for deterrence. }\end{array}\right.$

3. If 100,000 days in prison for Blodgett are not necessary for deterrence, then 99,999 days and 23 hours in prison are also not necessary for deterrence.

Sorites

Reasoning

X. If 1 day and 1 hour in prison for Blodgett are not necessary for deterrence, then 1 day in prison is also not necessary for deterrence.

False $\left\{\begin{array}{l}\text { C1. So } 1 \text { day in prison for Blodgett is not necessary for deterrence. } \\ \text { C2. So } 1 \text { day in prison for Blodgett both is and is not necessary for deterrence. }\end{array}\right.$

This seems like flawless reasoning once again. Paradoxical, yes, but flawless. But if MP is true, then it follows that the official both ought to sentence Jackie to at least 1 day in prison and ought to not sentence Jackie to even just 1 day in prison. This is clearly false. And since there are circumstances where MP delivers a false prescription (due to sorites reasoning), MP is false. ${ }^{7}$

\footnotetext{
7 This kind of reasoning is taken seriously in the philosophy of law. Hrafn Asgeirsson (2019, 233), for example, suggests that "the mere fact that legislation is riddled with predicates that admit of borderline cases shows that some legal cases cannot be resolved in a principled way," and Timothy Endicott (2000, 188190) offers a similar argument, based on the vagueness of "within a reasonable time," for the conclusion that the standard notion of the "rule of law" must be reconceived.
} 
We can now state van Inwagen's first argument against R4* more carefully in the following way:

\section{van Inwagen's Direct Argument}

V1. If $\mathrm{R} 4 *$ is true, then MP is true.

V2. If MP is true, then the official in Sentence ought to not sentence Blodget to even a single day in prison.

V3. It is not true that the official in Sentence ought to not sentence Blodget to even a single day in prison.

C1. So R4* is false.

This argument is "direct" since it appeals to nothing controversial regarding the problem of evil itself. And while it only targets R4*, I will consider it as a challenge to R4 as well and, consequently, consider its failure to undermine R4* as a failure to undermine R4.

\section{2. van Inwagen's Indirect Argument}

van Inwagen's indirect argument, on the other hand, appeals to a particular account of God's reasons for allowing evil. In a series of works, van Inwagen has outlined what he at first called a free will "theodicy" $(1988,163)$ and later called an expanded free will "defense" (2001, 66; 2006, 84). I here quote him selectively but representatively, picking and choosing the most illuminating bits from the relevant works: 
Part of the goodness of the world is that it contains "self-aware beings capable of abstract thought and love and having the power of free choice between contemplated alternative courses of action" (2006, 71), beings, most importantly perhaps, "fit to be loved by God and to love Him in return and to love one another" $(1988,163)$.

Some of God's creatures, however, "instead of loving Him and submitting to His will, chose to turn away from Him" (1988, 163). "They abused the gift of free will and separated themselves from their union with God" (2006, 86). "In turning away from God, our ancestors ruined themselves; they became unable to turn back to Him of their own power" (1988, 164).

But "God has not left His creatures to their misery" $(1988,165)$. Instead, he has "set in motion a rescue operation," "a plan designed to restore separated humanity to union with himself," a plan whose "object is to bring it about that human beings once more love God" (2006, 87).

Yet "in order to achieve Atonement with God, a ruined creature must tum to God and ask for His help and accept that help" $(1988,165)$. Humans must cooperate with their rescuer. And, for that, "they must know that they need to be rescued. They 
must know what it means to be separated from him. And what it means to be separated from God is to live in a world of horrors" (2006, 88). Consequently, in order to achieve the objective of rescuing his creatures, God "must leave in place a vast amount of evil," otherwise he would "deceive us about what separation from him means" (2006, 88).

I am not interested in whether this is a plausible story to most readers. What I am interested in here is the fact that, if this is more or less correct, then we have an answer to the question of why God allows for so much evil in the world. Simple: the existence of a great quantity of evil is necessary so that humans can comprehend their situation and freely decide to collaborate with God's rescue plan. To put it more succinctly, we can say that, for van Inwagen, the existence of a great quantity of evil is (plausibly) necessary for the success of God's rescue plan. Let's suppose that's true.

This claim, however, seems to have important consequences for R4*, since the predicate "is necessary for the success of God's rescue plan" is plausibly vague (cf. Schrynemaker 2006). We can see these consequences more clearly by following van Inwagen in taking two argumentative steps. The first step comes in the following claims:

[God] cannot remove all the horrors from the world, for that would frustrate his plan for reuniting human beings with himself. And if he prevents only some horrors, how shall he decide which ones to prevent? Where shall he draw the line?... I suggest 
that wherever he draws the line, it will be an arbitrary line. $(2006,105)$

Why? Because:

There is no minimum number of horrors consistent with God's plan of reconciliation, for the prevention of any one particular horror could not possibly have any effect on God's plan. For any n, if the existence of at most $\mathrm{n}$ horrors is consistent with God's plan, the existence of at most $\mathrm{n}-1$ horrors will be equally consistent with God's plan. (2006, 106)

van Inwagen is here telling us that "is necessary for the success of God's rescue plan" is subject to Tolerance. Take any amount of evil and whatever you say regarding it being necessary or not for the success of God's rescue plan, that assessment will not change with the addition or subtraction of just one more instance of evil. Following Jordan (2003, 237), we can call this van Inwagen's no minimum claim.

If the no minimum claim is true, however, then the attempt to eliminate all unjustified evils would place God into the same situation as that of our dedicated and conscientious groundskeeper and of the official in Sentence. But this is precisely what R4* would ask of God. (I leave it to the reader to spell out the relevant sorites argument.) van Inwagen's second argumentative step, then, is simply the recognition that the vagueness of the relevant predicate is incompatible with the expectations and demands that follow from R4*: 
If there is no minimum of evil that would serve God's purposes, then one cannot argue that God is unjust or cruel for not "getting by with less evil. (1988, 167)

I have argued elsewhere that, for any amount of suffering that somehow serves God's purposes, it may be that some smaller amount of suffering would have served them as well. It may be, therefore, that God has had to choose some amount of suffering as the amount contained in the actual world, and could, consistently with His purposes, have chosen any of a vast array of smaller or greater amounts, and that, all of the members of this vast array of alternative amounts of suffering are morally equivalent. (1991, 144)

If the story is true, much of the evil in the world is due to chance... According to the story I have told, there is generally no explanation of why this evil happened to that person. What there is, is an explanation of why evils happen to people without any reason... And the explanation is: that is part of what being separated from God means; it means being the playthings of chance. It means living in a world in which innocent children die horribly, and it means something worse than that: it means living in a world in which innocent children die horribly for no reason at all. $(2006,89)$

In each of these three statements, what van Inwagen is telling us is that his expanded free will defense is incompatible with R4*. If the story is true, then there must be instances of evil that occur for no reason at all, since any amount that fits God's purpose will be such that eliminating 
some particular evil would not frustrate those purposes, and since the attempt to eliminate all evils that are not necessary would, in turn, frustrate his purposes.

We can now state van Inwagen's second argument against R4* more carefully in the following way:

\section{van Inwagen's Indirect Argument}

V4. There is no minimum amount of evil that is necessary for the success of God's rescue plan.

V5. If there is no minimum amount of evil that is necessary for the success of God's rescue plan, then there must be instances of evil that occur for no reason at all.

V6. If there must be instances of evil that occur for no reason at all, then R4* is false.

C2. So R4* is false.

This argument is indirect since it does appeal to substantive views regarding the problem of evil. It has attracted some attention. Jeff Jordan (2003, 2011, 2014), for example, has challenged van Inwagen's no minimum claim (i.e., V4) as either false or implausible. Klaas Kraay (2013, 2014), for another example, has criticized the resulting picture of God's relationship to his creation as depending on the dubious rationality of satisficing: of knowingly choosing the less than best. These are important challenges, but my focus will be 
elsewhere. ${ }^{8}$ Once again, while this argument only targets R4*, I will consider its success or failure as indicative of the fate of R4 as well.

\section{The Plurality of Justifications}

I now want to argue that both V2 and V5 are false. Recall:

V2. If MP is true, then the official in Sentence ought to not sentence Blodget to even a single day in prison.

V5. If there is no minimum amount of evil that is necessary for the success of God's rescue plan, then there must be instances of evil that occur for no reason at all.

The reason why these claims are false, in fact, is the same. Their truth presupposes that the relevant agent - the official in Sentence and God - can only have one source of justifying reasons for allowing or preventing the relevant evil. Once we correct for this oversight, however, we see that the antecedents of V2 and V5 can both be true, while their consequents are false. As we will see, this does not require us to deny that principles subject to practical soritification are false, or that the predicates "is necessary for deterrence" and "is necessary for the success of God's rescue plan" are vague.

${ }^{8}$ See Cullison (2011) and Dragos (2013) for discussions of Jordan's argument. See Tucker $(2016,2020)$ for discussions of Kraay's argument.

Manuscrito - Rev. Int. Fil. Campinas, v. 44, n. 4, pp. 49-82, Oct.-Dec. 2021. 


\subsection{The Problem}

Consider V2 first. In his description of the case, van Inwagen $(2006,101)$ tells us: "Let's suppose that the only good that results from someone's being in prison is the deterrence of crime." That's a perfectly fine assumption. What is a mistake, however, is assuming that the only considerations that count as justifying reasons for the official in Sentence, or that pertain to outweighing goods and evils in this case, are those referring to reasons, goods, and evils that, in particular, result from someone's being in prison. The problem, in other words, is the move from there being just one good served by prison to the further claim that one's reasons for or against letting Blodgett out are governed exclusively by that good. What about other goods and evils, and other reasons, that are relevant to the official's decision? For example, what about reasons related to fairness to similarly positioned prisoners who have had to serve their term in full in the past?' The mistake behind V2, therefore, is not the simplifying assumption that van Inwagen worries about that there is just one good relevant to incarceration - but rather the assumption that there is just one good relevant to the official's decision. The former can be true while the latter is false. But if that's the case, then the antecedent of V2 can be true while its consequent false. ${ }^{10}$

9 As John Rawls $(1971,237)$ puts it, "the rule of law... implies the precept that similar cases be treated similarly. Men could not regulate their actions by rules if this precept were not followed." 10 The same applies to van Inwagen's vaccination example a bit later in the text, where at the end he says: "no matter what the authorities do, they will have to permit the death of a child they could have saved, or almost certainly could have saved, without achieving any good by permitting that child's death" $(2006,111)$. But this does not entail that the decision to distribute the vaccine in some way was arbitrary (i.e., made on the basis of no justifying

Manuscrito - Rev. Int. Fil. Campinas, v. 44, n. 4, pp. 49-82, Oct.-Dec. 2021. 
The point here, notice, is not that the consideration I mentioned is indeed a good enough justification for denying the request for a shorter sentence. The point is simply to illustrate the fact that the official in Sentence can have different sources of justifying reasons for permitting the relevant evil, some of which do not make central use of vague predicates. Even though (by reductive stipulation) the reasons related to the goods and evils of incarceration are by themselves incapable of guiding the official towards a non-arbitrary decision, these reasons need not be the only relevant ones.

Now consider V5. It focuses on the vagueness inherent in one of God's possible reasons for allowing evil and it infers from this that, since this reason cannot by itself eliminate arbitrary evils, they must exist. But when van Inwagen $(2006,108)$ tells us that God "had to draw an arbitrary line, and he drew it," van Inwagen is mistaking what God "had to do" with respect to the particular reason of having enough evil for the success of his rescue plan with what God "had to do" all things considered. From the fact that one of his reasons for permitting evil calls for an arbitrarily large amount of evil it does not follow that the amount of evil God permits must be arbitrary. Suppose God has justifying reasons to permit each of $n$ particular instances of evil. Nothing in van Inwagen's expanded free will theodicy/defense forces us to assume that $n$ is not large enough for God's rescue plan. Or start by supposing that $n$ is a large enough amount of evil for the success of God's rescue plan. Once again, nothing in van Inwagen's expanded free will theodicy/defense forces us to assume that God

reason), or that the decision to deny the request from Charlie's mom was arbitrary (i.e., made on the basis of no justifying reason). All it means is that the justifying reason could not have been exclusively "we are saving every life we can."

Manuscrito - Rev. Int. Fil. Campinas, v. 44, n. 4, pp. 49-82, Oct.-Dec. 2021. 
cannot have justifying reasons to permit each particular instance of evil as well. But if that's the case, then the antecedent of V5 can be true while its consequent false.

Of course, one could add an "exhaustiveness" claim to the view under consideration, namely that God's only justifying reason for permitting suffering (all and any of it) is that a large amount of it is required for his rescue plan. van Inwagen's second argument, after all, already appeals to substantive views regarding the problem of evil; it's no extra burden to modify it. Yet this additional exhaustiveness claim is something that van Inwagen $(2006,103)$ himself explicitly resists, telling us that "both the Hebrew Bible and the New Testament imply" that "some horrors are brought about by God, in each case to achieve some specific end" (2006, 103), and, more emphatically:

I do not claim that the theodicy I shall offer is comprehensive. That is, while I shall ascribe to God certain reasons for allowing evil to exist, I do not claim to give all of His reasons, or even to claim that the reasons I shall give are His most important reasons. For all I know God has reasons for allowing evil to exist that no human being could understand; perhaps, indeed, $\mathrm{He}$ has hundreds of perfectly good reasons that no possible creature could understand. (1988, 161).

It seems to me that van Inwagen's position is here entirely correct. It would take a special kind of epistemic hubris to insist that God in fact does not have any justifying reasons besides the ones that we have managed to identify. But without this additional claim, all we are left with is the claim 
that (plausibly) one of God's reasons for permitting evil necessitates a range of, but not a precise amount, duration, intensity, or distribution, of suffering. And that's not enough for a successful challenge to R4. ${ }^{11}$

\subsection{Rescuing van Inwagen?}

I want to consider two replies to my criticism of V2 and V5. The first reply comes in defense of van Inwagen's direct argument and suggests that there might be cases where all of the justifying reasons - or all of the relevant goods and evils - are mired in vagueness and, consequently, subject to the same concerns. ${ }^{12}$ Perhaps we can modify Sentence into a case where Blodgett is the very first person in that community convicted of a crime, or where Blodgett is the rebellious sailor in a shipwrecked crew in a desert island. In these kinds of cases, concerns related to precedent and fairness are

\footnotetext{
${ }^{11}$ A bit differently, one can always insist that, since we are in the dark about many of God's justifying reasons and in the dark about whether what we know is representative of what we don't know, we are also in the dark about whether or not all of God's other justifying reasons do or do not involve vague predicates. And since R4 will be true only if God's other justifying reasons do not involve vague predicates, it follows that we are in the dark as to whether or not R4 is true. This reply will sound familiar to anyone who knows the skeptical theist's reply to R2. What matters presently, however, is simply that this is very much not what van Inwagen's arguments are trying to show. van Inwagen's arguments purport to show that R4 is false, not that we are in the dark about its truth. That's what makes these arguments distinctive. My claim here is that his argument fails to establish what it aims to establish: The expanded free-will theodicy/defense casts no doubt on R4*. I'm grateful to Timothy Perrine for pressing me on this point.

${ }^{12}$ I'm grateful to Alex Pruss for mentioning this possibility.
} 
moot, and perhaps deterrence is the only relevant good, the only source of justifying reasons. Strictly speaking, none of this is a defense of V2, since V2 makes reference to the case as presented by van Inwagen. But the suggestion here is that we can still show that MP is subject to practical soritification if we only refine that case well enough. If there is even just one case where MP lands us in trouble, then MP is false. And if $\mathrm{MP}$ is the only "moral principle that it would be plausible to appeal in defense of" R4* (I won't challenge that claim here), then finding one such case would be enough to show that $\mathrm{R} 4 *$ is false too.

Any case appealing to "deterrence," however, needs to be mindful of the importance of following through on sentences. While it may be true that the amount of time necessary for deterrence is vague, it is not true that everything that is necessary for deterrence is vague as well. Another important aspect of deterrence, in fact, is the vividly felt sense that requests for shorter sentences - at least those that are not based on well-established legal provisions won't be obliged. Part of the deterring power of the law, in other words, is precisely its terrifying inflexibility. So even in isolated cases such as the ones above, cases where it seems like only deterrence is a source of justifying reasons, one can still have a reason to allow the evil of one more day in prison - i.e., one more day in prison can still promote the greater good of deterrence - despite the fact that the amount of time necessary for deterrence is vague.

In order to show that MP (or its normatively-generic abstraction) is false on grounds of soritification, we need a case where MP lands us in trouble with sorites reasoning. I have argued that van Inwagen's Sentence and some natural modifications of it do not constitute such kind of case. My bet, moreover, is that nothing will constitute such a case, but 
it is hard to say more about this matter presently without a systematic study of many more examples. I leave that for another time.

The second reply comes in defense of van Inwagen's indirect argument and it suggests that my criticism has misunderstood the dialectical role of van Inwagen's expanded free will theodicy/defense. In the continuation of the very same passage cited above, where van Inwagen (1988, 161-2) expresses his epistemic humility, he also tells us that

What I claim for the theodicy presented in this essay is this: it alleges a reason, or an interconnected set of reasons, that God has for allowing evil - of the amounts and kinds we observe - to come to be and to continue; if these were the only reasons God had for permitting evil, they would by themselves justify this permission. (My emphasis)

The suggestion now, then, is that while van Inwagen's story is in principle compatible with there being no pointless evil (on account of God's other possible reasons), its dialectical function resides in considering what follows from the possibility of that story being the entire truth of the matter. ${ }^{13}$

13 At other times, van Inwagen only tells us that his story is "is true for all anyone knows; or, at any rate, it is true, for all anyone knows, given that there is a God" $(2001,66)$, and that "if I offer a story about God and evil as a defense, I hope for the following reaction from my audience: 'Given that God exists, the rest of the story might well be true. I can't see any reason to rule it out"' $(2006,66)$. For the reasons given shortly in the main text, it seems to me that these are more sensible statements of the dialectical role of his expanded free will theodicy/defence. 
No one can fathom the vast array of reasons recognized by God, but if we can identify even just one reason that would justify God's permission of the evils that we see, then we have succeeded in showing that a perfect God is compatible with the existence of that evil. And if that evil happens to be pointless, then we have ipso facto shown that a perfect God is compatible with pointless evil as well. This is all fair enough.

The problem, of course, is that van Inwagen's expanded free will theodicy/defense shows no such thing about pointless evil. In fact, taken as the whole story about God's reasons, it shows nothing about the compatibility of a perfect God with evil of any kind. On the assumption that God's rescue plan is a morally permissible end, the story only entails that God is prima facie justified in permitting a large amount of evil. This is because the story also entails, assuming van Inwagen's no minimal claim is correct, that there will be pointless evils in a world where God chooses to carry out His rescue plan and has no other reasons for permitting evil than the one's related to what is necessary for the success of that plan. But what the story does not entail, on all of the same assumptions, is that God is permitted to allow pointless evil.

Indeed, when we force ourselves to consider the expanded free will theodicy/defense as the complete story about God's reasons for evil, we are left with a choice between accepting that those reasons are by themselves sufficient for making God all-things-considered justified in permitting a large amount of evil and between accepting that they are not. But what decides this question, crucially, is whether we think a perfect God is compatible with pointless evil. Nothing in van Inwagen's story can decide that for us. Nothing in the story entails an answer to this question, even under the relevant assumptions. To suggest otherwise is 
simply to stipulate that God's perfection is compatible with pointless evil, much like one stipulates that God's rescue plan is a morally permissible end. Yet while the latter is an unproblematic stipulation in this context, the former is not: part of the alleged point of the story, after all, is to support the former claim. And while drawing support for something always requires stipulations, it is hardly appropriate to stipulate the very thing one is trying to support.

\section{Conclusion}

At the heart of one of the most widely discussed arguments for the reasonableness of disbelief in God is a claim that is often taken as the only common ground in the literature on the problem of evil:

R4. If there is even one instance of suffering for which there is no justifying reason, then God does not exist.

Peter van Inwagen is one of a few to recently challenge this claim. ${ }^{14}$ Yet while van Inwagen identifies an important worry for principles appealing to vague predicates and succeeds in showing that some of God's possible reasons employ vague predicates in potentially problematic ways, he nonetheless fails to show that these concerns materialize as problems for R4. It thus continues to seem to me that Rowe's Evidential Argument From Evil succeeds in establishing its very modest conclusion: it is reasonable to believe that God does not exist if, after careful reflection on our experience and

14 Others include Mark Murphy (2017) and Daniel Rubio (2019). My criticism of van Inwagen's arguments here do not apply to their arguments. 
knowledge, we see no justifying reason for many instances of suffering in the world. van Inwagen's arguments, at least, don't seem to give us any reason to think otherwise.

\section{References}

Adams, Marylyn McCord (1999). Horrendous Evils and the Goodness of God. Cornell University Press.

Alston, William (1996). "The Inductive Argument from Evil and the Human Cognitive Condition," in Daniel Howard-Snyder (ed.), The Evidential Argument From Evil. Indiana University Press: 97-125.

Asgeirsson, Hrafn (2019). "The Sorites Paradox in Practical Philosophy," in The Sorites Paradox. Cambridge University Press: 229-245.

Bergmann, Michael (2001). "Skeptical Theism and Rowe's New Evidential Argument from Evil," Nous 35: 27896.

Cullison, Andrew (2011). "A Defence of the No-Minimum Response to the Problem of Evil," Religious Studies 47 (1): 121-123.

Dragos, Chris (2013). "The No-Minimum Argument, Satisficing, and No-Best-World: A Reply to Jeff Jordan”. Religious Studies 49 (3): 421-429.

Endicott, Timothy (2000). Vagueness in Law. Oxford University Press.

Hick, John (1966/2010). Evil and the God of Love. Palgrave Macmillan.

Jordan, Jeff (2003). "Evil and van Inwagen," Faith and Philosophy 20 (2): 236-239. 
. (2011). "Is the no-minimum claim true? Reply to Cullison," Religious Studies 47 (1): 125-127.

. (2014). "The No-Minimum Argument and Satisficing: a Reply to Chris Dragos," Religious Studies 50 (3): 379-386.

Kamp, Hans (1981). "The Paradox of the Heap", in Uwe Mönnich (ed.), Aspects of Philosophical Logic, Dordrecht. Reidel, 225-277.

Kraay, Klaas (2013). "Can God Satisfice?" American Philosophical Quarterly 50 (4): 399-410.

. (2014). "Peter van Inwagen on Gratuitous Evil," Religious Studies 50 (2): 217-234.

Murphy, Mark (2017). God's Own Ethics: Norms of Divine Agency and the Argument from Evil. Oxford University Press.

Oliveira, Luis R.G. (2020). "Skeptical Theism and the Paradox of Evil," Australasian Journal of Philosophy 98 (2):319-333.

Perrine, Timothy and Wykstra, Stephen (2012). "The Foundations of Skeptical Theism," Faith and Philosophy 29 (4): 375-399.

Plantinga, Alvin (1974). God, Freedom, and Evil. Harper and Row Publishers.

Rawls, John (1971). A Theory of Justice. Harvard University Press.

Raffman, Diana 2014, Unruly Words: A Study of Vague Language, Oxford: Oxford University Press.

Rowe, William (1979). "The Problem of Evil and Some Varieties of Atheism," American Philosophical Quarterly 16(4): 335-341.

Manuscrito - Rev. Int. Fil. Campinas, v. 44, n. 4, pp. 49-82, Oct.-Dec. 2021. 
Rubio, Daniel (2019). “God Meets Satan's Apple: The Paradox of Creation," Philosophical Studies 175: $2987-$ 3004.

Schrynemaker, Michael (2006). "Vagueness and Pointless Evil," Proceedings of the American Catholic Philosophical Association 80 245-254.

Sorensen, Roy 2001, Vagueness and Contradiction, New York: Oxford University Press.

Sullivan, Meghan (2013). "Peter van Inwagen's Defense," in Blackwell Companion to the Problem of Evil. eds. Daniel Howard-Snyder and Justin McBrayer. Oxford: WileyBlackwell: pp. 396-410.

Tucker, Christopher (2016). "Satisficing and Motivated Submaximization (in the Philosophy of Religion)," Philosophy and Phenomenological Research 93 (1): 127-143.

Tucker, Christopher (2020). "Divine Satisficing and the Ethics of the Problem of Evil," Faith and Philosophy 37 (1): 32-56.

van Inwagen, Peter (1988). "The Magnitude, Duration, and Distribution of Evil: A Theodicy," Philosophical Topics 16: 161-187. . 1991). "The Problem of Evil, the Problem of Air, and the Problem of Silence," Philosophical Perspectives 5: 135-165. . (2001). "The Argument from Particular Horrendous Evils," Proceedings of the American Catholic Philosophical Association 74: 65-80. . (2006). The Problem of Evil. Oxford University Press.

Williamson, Timothy 1994, Vagueness, London: Routledge. 
Wright, Crispin, 1975, "On the Coherence of Vague Predicates", Synthese, 30(3-4): 325-365.

Wykstra, Stephen (1984). "The Humean Obstacle to Evidential Arguments from Suffering: On Avoiding the Evils of Appearance," International Journal for Philosophy of Religion 16 (2): 73-93.

$(c c)$ EY

Manuscrito - Rev. Int. Fil. Campinas, v. 44, n. 4, pp. 49-82, Oct.-Dec. 2021. 